\title{
Carbohydrates digestibility and faecal nitrogen excretion in rats fed raw or germinated faba bean (Vicia faba)- and chickpea (Cicer arietinum)-based diets
}

\author{
Luis A. Rubio \\ Estación Experimental del Zaidín, Unidad de Nutrición, Profesor Albareda 1, 18008 Granada, Spain
}

(Received 23 October 2002 - Revised 14 March 2003 - Accepted 3 April 2003)

\begin{abstract}
Raw or germinated faba bean (Vicia faba minor var. Alameda) and chickpea (Cicer arietinum kabuli var. Athenas) seed meals were incorporated in essential amino acid-supplemented and energy-equalized diets for growing (65 (SD 1)g) male Wistar rats as the only sources of dietary protein. A lactalbumin-based diet was used as the control. Faecal dry weight and $\mathrm{N}$ excretion of animals fed legume-containing diets were greater $(P<0 \cdot 01)$ and DM digestibility lower $(P<0 \cdot 01)$ than controls. Apparent faecal digestibilities of amino acids were found to be not different or lower $(P<0.01)$ than controls in rats fed diets containing legume seeds, either germinated or not. Total diaminopimelic acid (DAPA) and purine bases excretion were significantly $(P<0 \cdot 01)$ higher than controls in rats fed both legume seed meals. Faecal bacterial N calculated according to DAPA or purine bases values was similar and significantly higher $(P<0 \cdot 01)$ than controls in rats fed legume seed meals. Bacterial $\mathrm{N}$ accounted for 50 to $80 \%$ of total faecal $\mathrm{N}$ in rats fed legume diets. Apparent faecal $\mathrm{N}$ digestibility values $(53-65 \%)$ of rats fed legume-based diets were lower $(P<0 \cdot 01)$ than controls, but became substantially higher (85-92\%) when calculated taking into account bacterial $\mathrm{N}$ values. Faecal NSP digestibility values for legume diets were $40-57 \mathrm{~g} / 100 \mathrm{~g}$ ingested. Germination decreased starch faecal excretion $(P<0 \cdot 05)$ and increased $(P<0 \cdot 05)$ faecal starch and NSP digestibilities of faba bean seeds.
\end{abstract}

Faba beans: Chickpeas: Germination: Carbohydrates and amino acids digestibility: Nitrogen excretion

Legume seeds such as faba beans (Vicia faba) and chickpeas (Cicer arietinum) are important protein sources for both human nutrition and animal production. While faba beans are mainly devoted to animal feeding, chickpeas are used for human consumption. Also, chickpea seeds, particularly those from the kabuli types (light-coloured), have been reported to contain relatively low amounts of anti-nutritional factors (Grant et al. 1983, 1995; Chavan et al. 1986). They appear to be well tolerated by singlestomached animals (Batterham et al. 1990; Savage \& Thompson, 1993) and constitute a staple food in great areas of the world including, for example, Mediterranean countries. Previous studies with legumes such as faba beans, chickpeas and lupins (Lupinus angustifolius) suggest that their low nutritional value is due to the inefficient utilization of their proteins by test animals. This appears to be due to lower nutritive quality of the major reserve proteins rather than to the presence of any known anti-nutritional factors (Rubio et al. 1991, 1995, 1998). Thus, in the rat, in vivo intestinal digestibility of isolated globulin preparations from faba bean, lupin and soyabean (Glycine max) was in fact higher than that of lactalbumin
(Rubio et al. 1994), which is frequently used as a control protein. Furthermore, since not only isolated protein fractions, but also individual amino acids, have shown ileal digestibility values comparable with control proteins (Rubio et al. 2002), the low utilization of some legume seed proteins is probably the result of other factors (Rubio, 2000).

Even though ileal digestibility of legume proteins appears to be high, faecal $\mathrm{N}$ excretion is usually higher than in controls. However, not only protein itself but also carbohydrate fractions in the diet have an effect on $\mathrm{N}$ digestibility and excretion, particularly through the metabolism of intestinal microbiota (Mathers, 1991). Thus, most of the $\mathrm{N}$ excreted through the faeces in man and animals fed diets rich in dietary fibre (NSP + lignin) is considered to come from bacterial fermentation in the large intestine (Cummings, 1984). In these circumstances, if faecal $\mathrm{N}$ excretion were not corrected for bacterial $\mathrm{N}$, faecal digestibility of dietary proteins would be underestimated. Bacterial $\mathrm{N}$ in faeces can be estimated by using diaminopimelic acid (DAPA) (Goodlad \& Mathers, 1990; Rubio, 2003a) or purine bases (Surra et al. 1997) 
as indirect markers of bacterial growth. These markers have been broadly used in ruminant nutrition where the relevance of bacterial metabolism in the intestinal tract has been always recognized. In the present work, both were used: first, due to the lack of information on these markers in single-stomached animals; second, in order to compare estimations from both methods.

Germination is regarded at present as one of the cheapest and most effective procedures to increase the nutritional value of legumes, supposedly through the breakdown of certain anti-nutritional factors such as phytates, protease inhibitors, lectins and $\alpha$-galactosides (de la Cuadra et al. 1994; Ayet et al. 1997; Greiner et al. 1998). Also, previous studies (Shekib, 1994; Urbano et al. 1995; Chitra et al. 1996; Mansour, 1996; Schulze et al. 1997) suggested an effect of germination mainly on the carbohydrate fraction of the seeds, together with higher digestibility values for both carbohydrates and proteins. Since most of these studies were conducted in vitro, it was considered appropriate to study the effects of germination on both $\mathrm{N}$ and carbohydrate digestibilities in vivo.

Accordingly, the aims of the present work were to study, in rats fed raw or germinated faba bean or chickpea diets: (a) the ileal and faecal digestibilities of carbohydrate fractions and amino acids; (b) the origin of the $\mathrm{N}$ excreted through the faeces.

\section{Materials and methods}

\section{Chemical analysis}

Faba bean (Vicia faba minor var. Alameda) and chickpea (Cicer arietinum var. Athenas) seeds were obtained from Centro de Investigación y Desarrollo Agrario (Córdoba, Spain). Seeds were screened for imperfections, placed on trays with sand-water $(5: 1, \mathrm{w} / \mathrm{v})$ and allowed to germinate for $72 \mathrm{~h}$ at $20^{\circ} \mathrm{C}$ in a constant environment chamber with a photoperiod of $8 \mathrm{~h} \mathrm{light/d}$. Seeds were then collected, freeze-dried and ground to pass a $1 \mathrm{~mm}$ sieve. Lactalbumin, DL- $\alpha \varepsilon$-DAPA, purine bases (adenine and guanine) and amino acids standards were obtained from Sigma (Poole, Dorset, UK).

Amino acids in feedstuffs and faeces were determined after hydrolysis of samples in boiling $\mathrm{HCl}(6 \mathrm{~mol} / \mathrm{l}$; $2 \mathrm{ml} / 5 \mathrm{mg}$ protein) for $18 \mathrm{~h}$ by using the Pico Tag method in HPLC equipment (Waters, Milford, MA, USA) (Fernández-Fígares et al. 1997). Carbohydrate (starch and NSP) analyses in feedstuffs and biological samples were carried out by GLC following the method of Englyst et al. (1992). DAPA in faecal samples was determined by reverse-phase HPLC (Rubio, 2003a). Briefly, freeze-dried faecal samples $(50-100 \mathrm{mg})$ were incubated in screwcapped tubes at $110^{\circ} \mathrm{C}$ for $24 \mathrm{~h}$ in $6 \mathrm{M}-\mathrm{HCl}$ for hydrolysis. After cooling, samples were diluted with water, internal standard ( $\alpha$-aminoadipic acid) was added to samples or standard solutions and dried under vacuum for $2 \mathrm{~h}$. Samples and standards were then re-dried for $1 \mathrm{~h}$ and derivatizing solution (phenylisothiocyanate) added, the tubes allowed to stand at room temperature for $15 \mathrm{~min}$ and vacuum-dried again. Samples were re-dissolved in $150 \mu \mathrm{l}$ Pico Tag sample diluent (Waters) for free amino acid analysis, vortex-mixed and $10 \mu \mathrm{l}$ solution injected for HPLC analysis in a $3.9 \times 300 \mathrm{~mm}$ Nova-Pak C18 column from Waters. Purine bases were also determined by reverse-phase HPLC (Balcells et al. 1992) using two Spherisorb (5 $\mu \mathrm{m})$ C18 ODS-2 $(4.6 \times 250 \mathrm{~mm})$ columns. Dried faecal samples $(100 \mathrm{mg})$ were added to $1 \mathrm{ml}$ allopurinol solution $(550 \mu \mathrm{mol}$ allopurinol/l) and hydrolysed for $1 \mathrm{~h}$ at $110^{\circ} \mathrm{C}$ with $\mathrm{HClO}_{4}$ ( $4 \mathrm{~mol} / \mathrm{l})$, followed by neutralization with $\mathrm{NaOH}(4 \mathrm{~mol} / \mathrm{l})$, centrifugation at $2000 \mathrm{~g}$ for $15 \mathrm{~min}$ and filtration of the supernatant fraction through a $0.2 \mu \mathrm{m}$ filter. $\mathrm{N}$ was determined by the Kjeldhal method (Association of Analytical Chemists, 1984). Chromium oxide in diets and ileal samples was determined as in Aguilera et al. (1988).

\section{Animals, diets and feeding regimen}

Six male weaned Wistar rats matched by weight (65 (SD 1)g) were used for each experimental treatment. They were housed individually in metabolism cages under controlled conditions of temperature $\left(25^{\circ} \mathrm{C}\right)$, relative humidity (50\%) and lighting (12 h light-dark cycles). All animals were pre-adapted to experimental conditions for $5 \mathrm{~d}$ before the experiment and fed the lactalbumin control diet. Feed was withheld overnight before the start of the experiment, which lasted for $9 \mathrm{~d}$. Feed allowance was restricted for all rats to $12 \mathrm{~g} \mathrm{feed} / \mathrm{d}$, which is close to the ad libitum feed intake of control animals of this age and weight. There were no feed refusals, and all animals readily ate all the feed offered to them. Water was freely available at all times. Rats were weighed daily. All management and experimental procedures carried out in the present study were done in strict accordance with the appropriate practices for management of laboratory animals in Spain (Act no. 223/88 of 14 March 1989) by staff trained to carry out such procedures.

The diets (Table 1) were based on raw (non-germinated) or germinated faba bean or chickpea seed meals and were equalized in digestible energy $(15.5 \mathrm{~kJ} / \mathrm{g})$ and protein (lactalbumin in controls or bean proteins plus synthetic amino acids, which were added as extra protein in the experimental diets). Total calculated amounts were (g/ $\mathrm{kg}$ ): lactalbumin control, 100; faba bean and germinated faba bean, 106.3; chickpea and germinated chickpea, $104 \cdot 8$. Crude protein was calculated as $N \times 6.25$ for lactalbumin and $\mathrm{N} \times 5.5$ for bean protein (Mossé, 1990). Appropriate amounts of synthetic essential amino acids were added to the legume-based diets taking into account their amino acid composition to reach or exceed control (lactalbumin) values (Table 1) where legume protein values were under requirements for diets containing $100 \mathrm{~g}$ protein $/ \mathrm{kg}$. Even though it is well established that added amino acids are not absorbed in the same way as those incorporated in a protein structure (Rérat et al. 1987), supplementation was carried out in order to rule out as much as possible the negative effects of amino acid imbalance on protein utilization. Due to the effects of caecal fermentation, the effects of supplementation on faecal amino acid excretion (as determined in the present study) are lower compared with those in ileal flows. The diets were also supplemented with vitamins and minerals to meet requirements (Grant et al. 1993). Chromium oxide ( $2 \mathrm{~g} / \mathrm{kg}$ diet) was added to 
Table 1. Composition $(\mathrm{g} / \mathrm{kg})$ of the diets

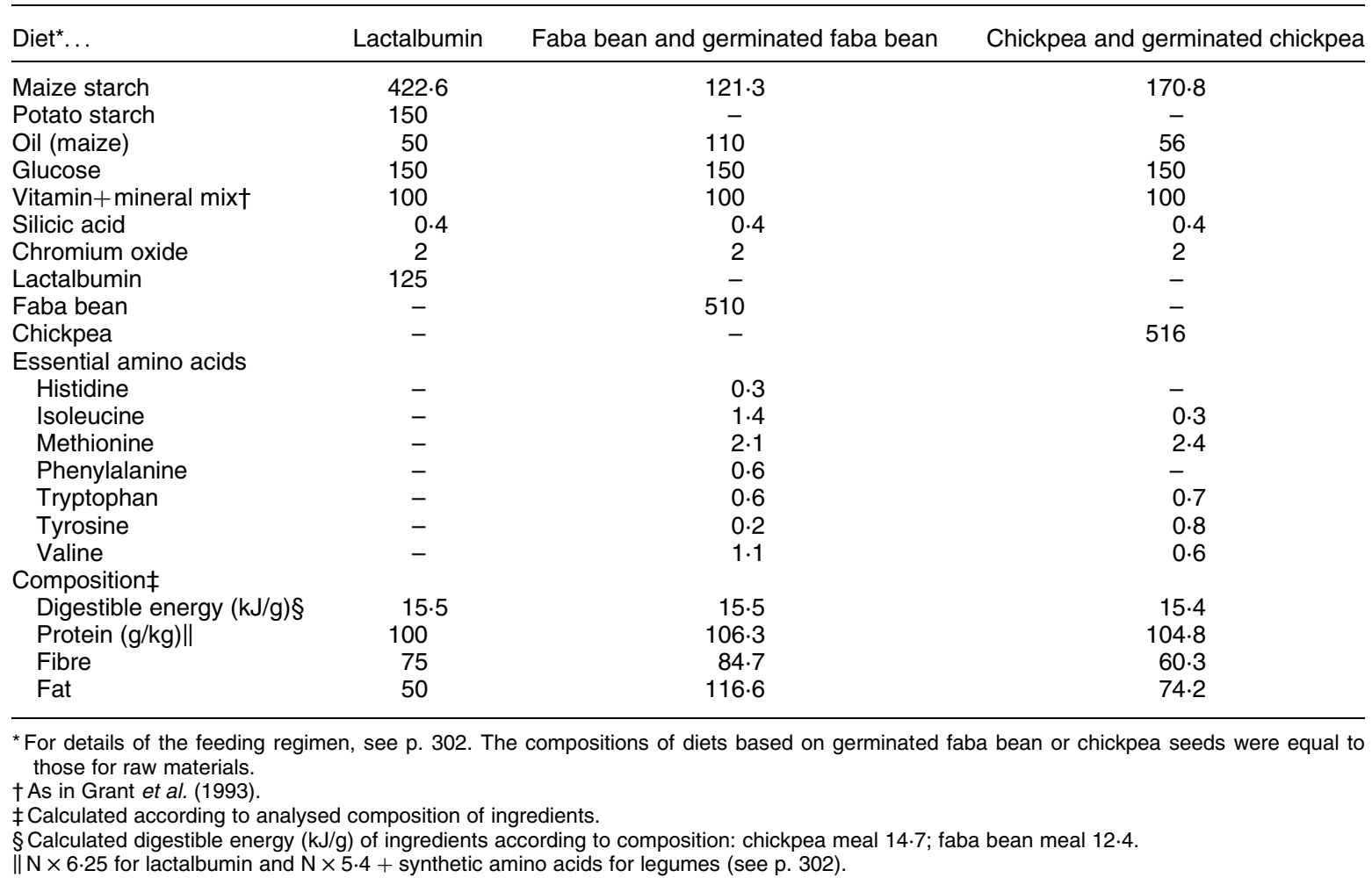

the diets as an indigestible marker. Potato and maize starch were the same as used in previous studies (Sigma catalogue nos. S4251 and S4126 respectively) (for example, see Rubio et al. 1995, 1998).

Amino acids apparent ileal digestibilities were calculated by using the expression:

$$
\left(\left(\mathrm{AA}_{\mathrm{f}} / \mathrm{Cr}_{2} \mathrm{O}_{3 \mathrm{f}}\right)-\left(\mathrm{AA}_{\mathrm{i}} / \mathrm{Cr}_{2} \mathrm{O}_{3 \mathrm{i}}\right)\right) /\left(\mathrm{AA}_{\mathrm{f}} / \mathrm{Cr}_{2} \mathrm{O}_{3 \mathrm{f}}\right) \text {, }
$$

where $\mathrm{AA}_{\mathrm{f}}$ and $\mathrm{AA}_{\mathrm{i}}$ are amino acid contents $(\mathrm{g} / 100 \mathrm{~g})$ and $\mathrm{Cr}_{2} \mathrm{O}_{3 \mathrm{f}}$ and $\mathrm{Cr}_{2} \mathrm{O}_{3 \mathrm{i}}$ are chromium oxide concentrations $(\mathrm{g} / 100 \mathrm{~g})$ in feed and ileal contents respectively. Starch and NSP apparent ileal digestibilities were calculated in the same manner. Apparent faecal digestibilities of amino acids, starch and NSP were calculated by difference between amounts ingested and excreted. Bacterial $\mathrm{N}$ in faeces was calculated by using DAPA and purine bases values according to the following expressions:

$$
\text { Bacterial } \mathrm{N}_{\mathrm{D}}(\mathrm{mg})=\begin{aligned}
19.45 \times \text { DAPA }(\mathrm{mg})+0.297 \\
(\text { Ahrens \& Kaufmann, 1985); }
\end{aligned}
$$

$$
\begin{array}{r}
\text { Bacterial } \mathrm{N}_{\mathrm{P}}(\mathrm{mg})=1.05 \times \text { purine bases }(\mu \mathrm{M}) \\
\text { (Surra } \text { et al. } 1997) .
\end{array}
$$

Corrected apparent faecal $\mathrm{N}$ digestibilities based on DAPA or purine bases in faeces (Table 2) were then calculated by subtracting bacterial $\mathrm{N}$ values from total faecal $\mathrm{N}$ excretion. Ileal and faecal legume starch digestibilities in legume diets were calculated assuming a $100 \%$ digestibility for maize starch as previously determined by others (Mathers et al. 1997) and by Rubio et al. (1995) in the control lactalbumin diets.

\section{Sampling procedures}

Rats were killed under pentobarbital sodium $(40 \mathrm{mg} / \mathrm{kg}$ body weight) anaesthesia on day 10 , exactly $2 \mathrm{~h}$ after giving them $5 \mathrm{~g}$ feed. The abdominal and thoracic cavities were opened, and ileal $(0-250 \mathrm{~mm}$ up from the ileocaecal junction) contents for digestibility measurements were washed out with ice-cold water, collected in plastic vials, immediately frozen $\left(-20^{\circ} \mathrm{C}\right)$, and subsequently freezedried. Faecal samples were collected daily throughout the study, stored at $-20^{\circ} \mathrm{C}$ until required, freeze-dried and ground in a mortar.

\section{Statistical analysis}

The results were subjected to a factorial $(2 \times 2)$ two-way ANOVA. The Tukey multiple comparison test was used to determine differences between means (Minitab Statistical Software Package; Minitab, New York, NY, USA).

\section{Results}

Analysed starch and NSP composition of raw and germinated legume seeds are described in Table 3. The carbohydrate composition of germinated faba bean and chickpea seeds was similar to those of non-germinated materials. Starch content in both legume seed meals was $405-429 \mathrm{mg} / \mathrm{g}$, while chickpea seeds contained lower amounts $(97-103 \mathrm{mg} / \mathrm{g})$ of total NSP than faba beans $(160-164 \mathrm{mg} / \mathrm{g})$. That difference was mainly due to lower glucose (cellulose) and uronic acid (pectins) amounts in chickpea seeds. 
Table 2. Excretion of total and bacterial nitrogen through the faeces, and calculated apparent faecal nitrogen digestibility values, in rats fed raw or germinated faba bean- or chickpea-based diets for $9 \mathrm{~d} \dagger$

(Mean values and pooled standard deviations)

\begin{tabular}{|c|c|c|c|c|c|c|c|c|c|}
\hline & \multirow[b]{2}{*}{ Lactalbumin } & \multirow[b]{2}{*}{$\begin{array}{l}\text { Faba } \\
\text { bean }\end{array}$} & \multirow[b]{2}{*}{$\begin{array}{l}\text { Germinated } \\
\text { faba bean }\end{array}$} & \multirow[b]{2}{*}{ Chickpea } & \multirow[b]{2}{*}{$\begin{array}{c}\text { Germinated } \\
\text { chickpea }\end{array}$} & \multirow[b]{2}{*}{$\begin{array}{l}\text { Pooled } \\
\text { SD }\end{array}$} & \multicolumn{3}{|c|}{ Probability } \\
\hline & & & & & & & $\mathrm{S}$ & $\mathrm{T}$ & $\mathrm{S} \times \mathrm{T}$ \\
\hline Dry weight (g) & $3 \cdot 9^{a}$ & $15 \cdot 1^{\mathrm{b}}$ & $12 \cdot 1^{c}$ & $9 \cdot 3^{d}$ & $9 \cdot 1^{d}$ & $1 \cdot 1$ & $\star *$ & $\star \star$ & ** \\
\hline Total N (g) & $0 \cdot 14^{a}$ & $0.89^{b}$ & $0 \cdot 80^{\mathrm{C}}$ & $0.68^{d}$ & $0.71^{d}$ & 0.50 & $\star *$ & NS & * \\
\hline App. $\mathrm{N}$ dig (\%) & $92 \cdot 0^{\mathrm{a}}$ & $53 \cdot 6^{\mathrm{b}}$ & $58 \cdot 3^{c}$ & $65 \cdot 1^{d}$ & $63 \cdot 9^{d}$ & $2 \cdot 5$ & $\star *$ & NS & * \\
\hline DM digestibility (\%) & $96 \cdot 3^{a}$ & $85 \cdot 8^{\mathrm{b}}$ & $88 \cdot 7^{c}$ & $91 \cdot 4^{d}$ & $91 \cdot 5^{d}$ & 0.9 & $* *$ & $\star \star *$ & ** \\
\hline Total DAPA (mg) & $7 \cdot 3^{a}$ & $36 \cdot 4^{\mathrm{b}}$ & $21 \cdot 7^{c}$ & $17 \cdot 5^{\mathrm{c}}$ & $21 \cdot 8^{\mathrm{c}}$ & 7.5 & * & NS & * \\
\hline Bacterial $N_{D}(\mathrm{mg})$ & $141 \cdot 3^{a}$ & $707 \cdot 5^{\mathrm{b}}$ & $422 \cdot 4^{\mathrm{C}}$ & $340 \cdot 4^{\mathrm{C}}$ & $424 \cdot 5^{\mathrm{C}}$ & $145 \cdot 3$ & * & NS & * \\
\hline App. $\mathrm{N} \operatorname{dig}_{\mathrm{D}}(\%)$ & $99 \cdot 7^{a}$ & $90 \cdot 5^{\mathrm{b}}$ & $82 \cdot 8^{\mathrm{b}}$ & $82 \cdot 9^{b}$ & $85 \cdot 3^{b}$ & 8.0 & NS & NS & NS \\
\hline Purine bases $(\mu \mathrm{M} / \mathrm{g})$ & $28 \cdot 6^{a}$ & $37 \cdot 4^{\mathrm{ab}}$ & $42 \cdot 4^{b}$ & $55 \cdot 2^{c}$ & $56 \cdot 1^{\mathrm{c}}$ & $7 \cdot 2$ & $\star \star$ & NS & NS \\
\hline Total purines $(\mu \mathrm{M})$ & $111 \cdot 9^{\mathrm{a}}$ & $558 \cdot 6^{\mathrm{b}}$ & $511 \cdot 7^{\mathrm{b}}$ & $507 \cdot 2^{\mathrm{b}}$ & $518 \cdot 9^{b}$ & 84.4 & NS & NS & NS \\
\hline Bacterial $N_{P}(m g)$ & $117 \cdot 4^{\mathrm{a}}$ & $586 \cdot 6^{\mathrm{b}}$ & $537 \cdot 2^{\mathrm{b}}$ & $532 \cdot 5^{b}$ & $544 \cdot 8^{b}$ & $88 \cdot 6$ & NS & NS & NS \\
\hline App. $\mathrm{N} \operatorname{dig}_{\mathrm{p}}(\%)$ & $94.9^{\mathrm{a}}$ & $84 \cdot 7^{b}$ & $88 \cdot 0^{a b}$ & $92 \cdot 4^{\mathrm{a}}$ & $91 \cdot 5^{\mathrm{a}}$ & $4 \cdot 1$ & $\star \star$ & NS & NS \\
\hline
\end{tabular}

$\mathrm{S}$, seed (faba bean or chickpea); $\mathrm{T}$, treatment (germinated or not germinated); App. N dig, apparent $\mathrm{N}$ digestibility; DAPA, diaminopimelic acid; Bacterial $\mathrm{N}_{\mathrm{D}}$, bacterial $\mathrm{N}$ in faeces calculated from DAPA values; App. $\mathrm{N}$ dig , apparent faecal $\mathrm{N}$ digestibility corrected for bacterial $\mathrm{N}$ according to faecal DAPA values; Bacterial $\mathrm{N}_{\mathrm{p}}$, bacterial $\mathrm{N}$ in faeces calculated from purine bases values; App. $\mathrm{N}$ dig , apparent faecal $\mathrm{N}$ digestibility corrected for bacterial $\mathrm{N}$ according to faecal purine bases values; NS, not significant $(P>0.05)$.

a,b,c,d Mean values within a row with unlike superscript letters were significantly different $(P<0.01)$.

${ }^{\star} P<0.05,{ }^{* \star} P<0.01$.

†For composition of the diets see Table 1 and p. 302.

Performance and $\mathrm{N}$ balance indices of rats fed these diets have been presented elsewhere (Rubio et al. 2002). Briefly, weight gains, gain:feed values, $\mathrm{N}$ retention and net protein utilization (NPU) values of rats fed diets containing raw or germinated legume seed meals as the only source of protein were lower $(P<0 \cdot 01)$ than controls. Rats fed germinated faba bean diets had higher $(P<0 \cdot 01)$ NPU values than those fed raw seed meal, while there was no difference between raw and germinated chickpea seeds with regard to rat performance and $\mathrm{N}$ balance.

Apparent faecal digestibilities of amino acids (Table 4) were found to be not different or lower $(P<0 \cdot 01)$ than controls in rats fed diets based on legume seeds, either germinated or not.

Faecal dry weight and $\mathrm{N}$ excretion by animals fed legumes were greater $(P<0 \cdot 01)$ and DM digestibility lower $(P<0.01)$ than controls (Table 2). On the other hand, although faecal DAPA concentration values $(1.81-2.45 \mathrm{mg} / \mathrm{g})$ were not different among treatments, total DAPA excretion was significantly $(P<0 \cdot 01)$ higher than controls in rats fed legume seed meals. Purine bases concentrations and total faecal excretions were higher
$(P<0.01)$ than controls in rats fed legume-based diets. Faecal bacterial $\mathrm{N}$ calculated according to DAPA or purine bases values was significantly higher $(P<0 \cdot 01)$ than controls in rats fed legume seed meals. Apparent faecal $\mathrm{N}$ digestibility values ranged between 53 and $65 \%$ and were significantly lower $(P<0 \cdot 01)$ than controls for rats fed legume seeds, either germinated or not. However, apparent faecal $\mathrm{N}$ digestibility values were substantially higher (85-92\%) when calculated taking into account bacterial $\mathrm{N}$ values (see p. 303 and Table 2). Apparent $\mathrm{N}$ digestibility values calculated according to purine bases in the faeces were not different from controls in germinated faba bean- and both chickpea-based diets. Bacterial $\mathrm{N}$ accounted for $50-80 \%$ of total faecal $\mathrm{N}$ in rats fed legume diets. Even though values were similar, bacterial $\mathrm{N}$ values estimated from purine bases values tended to be higher than those estimated from DAPA.

Germination of faba beans decreased $(P<0 \cdot 05)$ faecal excretion of starch (Table 5), tended to increase ileal starch and NSP digestibilities and significantly $(P<0.05)$ improved faecal starch and NSP digestibilities, while no effect was observed with germinated compared with raw

Table 3. Carbohydrates (starch + non-starch polysaccharides) composition ( $\mathrm{mg} / \mathrm{g}$ dry matter) of raw and germinated faba bean and chickpea seed meals

\begin{tabular}{|c|c|c|c|c|}
\hline & Faba bean & Germinated faba bean & Chickpea & Germinated chickpea \\
\hline Starch & 421 & 429 & 405 & 415 \\
\hline Rhamnose & 3.0 & $3 \cdot 3$ & $2 \cdot 3$ & 3.2 \\
\hline Arabinose & $18 \cdot 6$ & $21 \cdot 7$ & 24.9 & $28 \cdot 9$ \\
\hline Xylose & $12 \cdot 2$ & $12 \cdot 3$ & 5.5 & $5 \cdot 1$ \\
\hline Mannose & $4 \cdot 0$ & $4 \cdot 0$ & $4 \cdot 8$ & $4 \cdot 8$ \\
\hline Galactose & $9 \cdot 7$ & $9 \cdot 4$ & $8 \cdot 7$ & $10 \cdot 0$ \\
\hline Glucose & $75 \cdot 2$ & $66 \cdot 3$ & $27 \cdot 9$ & $28 \cdot 2$ \\
\hline Uronic acids & $41 \cdot 5$ & $43 \cdot 3$ & $23 \cdot 8$ & $23 \cdot 0$ \\
\hline Total NSP & $164 \cdot 2$ & $160 \cdot 3$ & 97.9 & 103.2 \\
\hline
\end{tabular}


Table 4. Apparent faecal digestibility ( $\mathrm{g} / 100 \mathrm{~g}$ ingested) of amino acids in rats fed diets containing raw or germinated faba bean or chickpea seeds as the only protein source $\dagger$

(Mean values and pooled standard errors)

\begin{tabular}{|c|c|c|c|c|c|c|c|c|c|}
\hline & \multirow[b]{2}{*}{ Lactalbumin } & \multirow[b]{2}{*}{$\begin{array}{l}\text { Faba } \\
\text { bean }\end{array}$} & \multirow[b]{2}{*}{$\begin{array}{c}\text { Germinated } \\
\text { faba bean }\end{array}$} & \multirow[b]{2}{*}{ Chickpea } & \multirow[b]{2}{*}{$\begin{array}{c}\text { Germinated } \\
\text { chickpea }\end{array}$} & \multirow[b]{2}{*}{$\begin{array}{c}\text { Pooled } \\
\text { SE }\end{array}$} & \multicolumn{3}{|c|}{ Probability } \\
\hline & & & & & & & $S$ & $\mathrm{~T}$ & $S \times T$ \\
\hline \multicolumn{10}{|l|}{ Essential } \\
\hline Arginine & 74 & 68 & 74 & 82 & 80 & 2 & NS & NS & NS \\
\hline Histidine & $79^{\mathrm{a}}$ & $57^{\mathrm{b}}$ & $58^{\mathrm{b}}$ & $68^{\mathrm{ab}}$ & $55^{\mathrm{b}}$ & 2 & NS & * & * \\
\hline Isoleucine & $87^{a}$ & $58^{\mathrm{b}}$ & $56^{\mathrm{b}}$ & $53^{\mathrm{b}}$ & $36^{c}$ & 2 & * & * & * \\
\hline Leucine & $92^{\mathrm{a}}$ & $61^{\mathrm{b}}$ & $59^{b}$ & $60^{\mathrm{b}}$ & $46^{c}$ & 2 & * & * & NS \\
\hline Lysine & $87^{\mathrm{a}}$ & $49^{\mathrm{b}}$ & $57^{\mathrm{b}}$ & $58^{\mathrm{b}}$ & $57^{\mathrm{b}}$ & 2 & NS & NS & $*$ \\
\hline Phenylalanine & $83^{\mathrm{a}}$ & $56^{\mathrm{b}}$ & $59^{b}$ & $69^{\mathrm{ab}}$ & $46^{\mathrm{b}}$ & 2 & NS & NS & * \\
\hline Threonine & $79^{a}$ & $55^{\mathrm{b}}$ & $51^{\mathrm{b}}$ & $67^{\mathrm{ab}}$ & $54^{\mathrm{b}}$ & 2 & NS & $*$ & NS \\
\hline Tyrosine & $87^{\mathrm{a}}$ & $57^{\mathrm{b}}$ & $57^{\mathrm{b}}$ & $71^{\mathrm{c}}$ & $55^{\mathrm{b}}$ & 2 & NS & * & $*$ \\
\hline Valine & $85^{\mathrm{a}}$ & $58^{\mathrm{bc}}$ & $55^{\mathrm{bc}}$ & $61^{b}$ & $43^{\mathrm{c}}$ & 2 & NS & * & * \\
\hline \multicolumn{10}{|l|}{ Non essential } \\
\hline Alanine & $81^{a}$ & $46^{\mathrm{b}}$ & $41^{\mathrm{b}}$ & $54^{\mathrm{b}}$ & $43^{b}$ & 3 & NS & NS & NS \\
\hline Aspartate & $88^{a}$ & $73^{\mathrm{b}}$ & $85^{a}$ & $83^{a}$ & $84^{a}$ & 1 & NS & * & NS \\
\hline Glutamate & $89^{\mathrm{a}}$ & $70^{\mathrm{b}}$ & $78^{\mathrm{b}}$ & $82^{\mathrm{ab}}$ & $78^{\mathrm{b}}$ & 1 & * & NS & $*$ \\
\hline Glycine & $61^{a}$ & $51^{\mathrm{ab}}$ & $53^{\mathrm{ab}}$ & $71^{\mathrm{b}}$ & $56^{\mathrm{ab}}$ & 2 & NS & NS & * \\
\hline Proline & $81^{\mathrm{a}}$ & $49^{b}$ & $55^{\mathrm{b}}$ & $73^{\mathrm{ab}}$ & $53^{\mathrm{b}}$ & 2 & NS & NS & * \\
\hline Serine & $77^{\mathrm{a}}$ & $60^{\mathrm{b}}$ & $65^{\mathrm{ab}}$ & $75^{\mathrm{a}}$ & $66^{\mathrm{b}}$ & 2 & NS & NS & * \\
\hline
\end{tabular}

$\mathrm{S}$, seed (faba bean or chickpea); T, treatment (germinated or not germinated); NS not significant $(P>0.05)$.

$\mathrm{a}, \mathrm{b}, \mathrm{c}$ Mean values within a row with unlike superscript letters were significantly different $(P<0.01)$.

${ }^{\star} P<0.05,{ }^{* \star} P<0.01$.

†For composition of the diets, see Table 1 and p. 302.

chickpea seeds (Table 6). Ileal starch digestibility in rats fed legume seed meals was $41-54 \mathrm{~g} / 100 \mathrm{~g}$ ingested, while in faeces values were $94-97 \mathrm{~g} / 100 \mathrm{~g}$ ingested. Faecal NSP digestibility values for legume diets were $40-57 \mathrm{~g} / 100 \mathrm{~g}$ ingested. Among individual sugars, higher digestibility values were determined for uronic acids, arabinose and mannose in both faba bean and chickpea meals.

\section{Discussion}

The inclusion of faba bean or chickpea seed meals in the diet resulted in lower performance (weight gain, gain:feed) and $\mathrm{N}$ retention and NPU values than lactalbumin controls. Germination of chickpea seeds brought about no significant improvement in these parameters as compared with raw materials, which is in keeping with previously published data (Khaleque et al. 1985). On the contrary, germination of faba beans resulted in higher $\mathrm{N}$ retention and NPU values compared with non-germinated seeds, even though values did not reach those of controls (Rubio et al. 2002). Previously reported experiments with germinated materials (Shekib, 1994; Urbano et al. 1995; Chitra et al. 1996; Mansour, 1996; Schulze et al. 1997) suggested an effect of germination mainly on the carbohydrate fraction of the seeds, together with higher digestibility values for both carbohydrates and proteins. Although most of these data referred to are from in vitro studies, and the agreement of in vivo with in vitro results is usually difficult

Table 5. Faecal starch and non-starch polysaccharides excretion $(\mathrm{mg} / \mathrm{g}$ dry matter) of rats fed diets containing raw or germinated faba bean or chickpea seeds as the only protein source

(Mean values and pooled standard deviations)

\begin{tabular}{|c|c|c|c|c|c|c|c|c|}
\hline & \multirow[b]{2}{*}{ Faba bean } & \multirow[b]{2}{*}{ Germinated faba bean } & \multirow[b]{2}{*}{ Chickpea } & \multirow[b]{2}{*}{ Germinated chickpea } & \multirow[b]{2}{*}{ Pooled SD } & \multicolumn{3}{|c|}{ Probability } \\
\hline & & & & & & $S$ & $\mathrm{~T}$ & $\mathrm{~S} \times \mathrm{T}$ \\
\hline Starch & $89^{a}$ & $61^{b}$ & $68^{b}$ & $60^{b}$ & 12 & * & $\star *$ & * \\
\hline Rhamnose & $5 \cdot 6^{a}$ & $6 \cdot 0^{\mathrm{a}}$ & $9 \cdot 6^{\mathrm{b}}$ & $9 \cdot 0^{\mathrm{b}}$ & $1 \cdot 7$ & $\star \star$ & NS & NS \\
\hline Arabinose & $26 \cdot 6$ & $24 \cdot 4$ & $64 \cdot 2$ & $37 \cdot 3$ & $27 \cdot 8$ & * & NS & NS \\
\hline Xylose & $46 \cdot 2^{\mathrm{a}}$ & $42 \cdot 5^{a}$ & $22 \cdot 5^{\mathrm{b}}$ & $19 \cdot 1^{b}$ & 6.6 & $\star \star$ & NS & NS \\
\hline Mannose & $7 \cdot 3^{a}$ & $7 \cdot 6^{\mathrm{a}}$ & $14 \cdot 0^{b}$ & $13 \cdot 6^{b}$ & 4.5 & * & NS & NS \\
\hline Galactose & $29 \cdot 3$ & $34 \cdot 2$ & $39 \cdot 2$ & $42 \cdot 5$ & $8 \cdot 4$ & * & NS & NS \\
\hline Glucose & $179 \cdot 5^{a}$ & $179 \cdot 0^{a}$ & $99 \cdot 9^{b}$ & $107 \cdot 1^{\mathrm{b}}$ & $33 \cdot 0$ & $\star *$ & NS & NS \\
\hline Uronic acids & $40 \cdot 2$ & 45.5 & $47 \cdot 6$ & $33 \cdot 8$ & 9.5 & NS & NS & * \\
\hline Total NSP & $355 \cdot 8^{a}$ & $327 \cdot 2^{\mathrm{ab}}$ & $277.9^{b}$ & $287 \cdot 1^{b}$ & $42 \cdot 7$ & * & NS & NS \\
\hline
\end{tabular}

$\mathrm{S}$, seed (faba bean or chickpea); T, treatment (germinated or not germinated); NS, not significant $(P>0.05)$.

$\mathrm{a}, \mathrm{b}, \mathrm{c}$ Mean values within a row with unlike superscript letters were significantly different $(P<0.05)$.

${ }^{\star} P<0.05,{ }^{\star *} P<0.01$.

†For composition of the diets, see Table 1 and p. 302. 
Table 6. Ileal and faecal starch and non-starch polysaccharides digestibilities ( $\mathrm{g} / 100 \mathrm{~g}$ ingested) of diets containing raw or germinated faba bean or chickpea seeds as the only protein source in rats $\dagger$

(Mean values and pooled standard deviations)

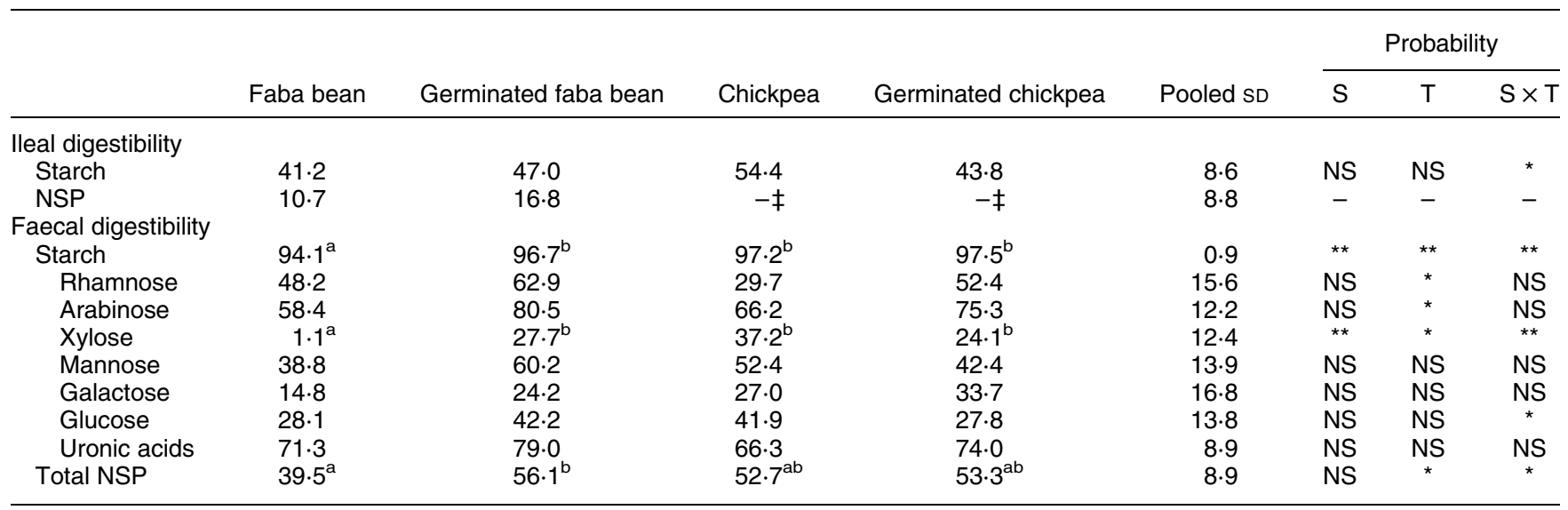

$\mathrm{S}$, seed (faba bean or chickpea); T, treatment (germinated or not germinated); NS, not significant $(P>0.05)$.

a,b,c Mean values within a row with unlike superscript letters were significantly different $(P<0.05)$.

${ }^{\star} P<0.05,{ }^{\star *} P<0.01$

†For composition of the diets, see Table 1 and p. 302.

$\ddagger$ Excessive variability of data.

to establish, faecal starch and NSP digestibility values in the present work (Table 6) were higher for germinated compared with non-germinated faba beans. Also, higher protein efficiency ratio, protein digestibility, biological value and ileal amino acid digestibilities have been previously reported in germinated as compared with raw faba beans (Khalil, 2001).

A number of explanations for the lower nutritional value of legume-based diets for growing single-stomached animals have been reported in the last few decades. Among those explanations, some deal with an alleged lower digestibility of their constituent fractions, particularly proteins. However, most data referred to are from in vitro studies or apparent faecal digestibility values, and less information exists on ileal in vivo digestibility values. Values recently reported (Rubio et al. 2002) indicate high apparent ileal digestibility of amino acids, which would suggest that legume proteins are well digested and absorbed within the small intestine. Nevertheless, apparent faecal amino acid digestibilities decreased (Table 4) and total faecal $\mathrm{N}$ excretion increased (Table 2) in legume-fed rats, which would apparently contradict the previous observation. However, it is important to keep in mind that high $\mathrm{N}$ excretion values are usually linked in single-stomached animals and man to high NSP dietary contents (Cummings, 1984; Mason, 1984; Bach Knudsen et al. 1991; Goodlad \& Mathers, 1992), as occurs in faba bean- and chickpea-based diets. Thus, raw faba bean and chickpea seed meals contain 164 and $97 \mathrm{~g} \mathrm{NSP} / \mathrm{kg}$ (Table 3), which resulted in 83 and $50 \mathrm{~g} \mathrm{NSP} / \mathrm{kg}$ diet for faba bean and chickpea diets respectively. The main reason for that higher faecal $\mathrm{N}$ excretion is that intestinal, and particularly lower gut, microflora increases its growth at the expense of undigested carbohydrates coming from the small intestine and urea supplied mainly through the large-intestinal wall. Goodlad \& Mathers (1990) found faecal $\mathrm{N}$ excretion values similar to those here reported in rats fed diets based on pea seed meal as the main protein source. The amounts of DAPA determined in that work by a different method increased by 3 -fold compared with controls, which agrees with the DAPA values determined in the present study (Table 2). Furthermore, faecal bacterial $\mathrm{N}$ calculated from purine bases excretion, which is determined independently from DAPA, and is also used as an indicator of bacterial growth (Surra et al. 1997), gave similar results. According to DAPA and purine bases excretion in faeces, bacterial $\mathrm{N}$ accounts for $50-80 \%$ of the total faecal $\mathrm{N}$ in faba bean- or chickpea-fed rats. When bacterial $\mathrm{N}$ was subtracted from total faecal $\mathrm{N}$, much higher apparent $\mathrm{N}$ digestibility values $(84-92 \%)$ were obtained. On the other hand, the inclusion in the diet of faba bean, chickpea and lupin isolated carbohydrate fractions, which contain most of the starch and NSP present in the whole seed meals, was previously found to give rise to total faecal $\mathrm{N}$ excretion values $(234-314 \mathrm{mg}$ ) higher than controls but significantly lower than those of rats fed diets containing whole legume seed meal. In addition, the inclusion of legume carbohydrate fractions in rat control diets had no effect on final NPU values, which were not different from controls (Rubio et al. 1991, 1995, 1998). Therefore, it seems to be not only the presence of energy-yielding substrates (usually undigested carbohydrates), but other factors in the meal that bring about higher $\mathrm{N}$ excretion in legumefed growing rats. The reason is probably that the intestinal flora overgrowth is also dependent on the presence of $\mathrm{N}$ sources, such as urea in plasma, which is taken from the intestinal wall (Mason, 1984), as previously suggested by others. Thus, Beames \& Eggum (1981) in rats and Mosenthin et al. (1992) in pigs showed that the presence of undigested (potato) starch allowed the assimilation by the intestinal flora of nitrogenous materials arising from the blood. Also, in diets differing in protein quality, not only the amount of $\mathrm{N}$ excreted in faeces but also in urine is affected by the type and fermentability of carbohydrates (Pastuszewska et al. 2000). This has also led to the suggestion that fermentation of a large amount 
of carbohydrates in the large intestine (which enhances the faecal excretion of bacterial $\mathrm{N}$ ) could be of value to minimize urea excretion by the kidneys when renal function is impaired (Rémésy \& Demigné, 1989). On the other hand, as both faba bean and chickpea diets raised blood urea concentrations, an effect also detected in rats fed purified legume proteins (Rubio et al. 1999), intestinal bacterial overgrowth and consequently increased faecal $\mathrm{N}$ excretion might depend indirectly at least in part on protein quality. Although the reasons for the lower protein utilization and increased urea production and $\mathrm{N}$ excretion in growing rats fed legume or legume protein-based diets compared with controls are still unclear, the explanation might be related to differences in the digestion-absorption process, as suggested by studies in Caco- 2 cell cultures. Thus, Rubio \& Seiquer (2002) observed that the rate of transport of amino acids from apical to basolateral chambers of Caco-2 cells grown in Transwell bicameral plates was slower for legume proteins hydrolysates compared with casein. That would be in keeping with lower amounts of amino acids afferent per unit of time from the intestine to the liver recently determined in rats fed legume-based diets compared with controls (Rubio, 2003b), which in turn might explain the observed effects on liver and whole-body $\mathrm{N}$ metabolism (Rubio et al. 1999) because the mix of amino acids available for protein synthesis in the tissues at a given moment could be imbalanced. This imbalance can lower the rate of protein synthesis, resulting in an increase in amino acid catabolism, lower protein retention values and increased $\mathrm{N}$ excretion in the form of urea. Therefore, lower apparent faecal amino acid digestibilities in rats fed legume-based diets are probably not mainly due to lower legume protein digestibility in the small intestine but to changes in protein metabolism leading to increased urea production (Rubio, 2000) and bacterial overgrowth in the large intestine at the expense of undigested starch and NSP present in the meal. Thus, according to results in Tables 3 and 6, substantial amounts of faba bean and chickpea starch (220-233 and 180-227 g respectively), and 58-75 $\mathrm{g}$ faba bean NSP were digested in the lower gut of the rats fed legume-containing diets, either germinated or not. This means that starch was actually the major source of carbohydrate delivered to the caecum of rats fed faba bean or chickpea diets.

Low small-intestinal digestibility and fermentation of legume carbohydrates in the lower gut have both health and productive implications. Legumes are at present regarded as low-glycaemic index foods, and high-carbohydrate low-glycaemic-index dietary advice has been found to improve $\beta$-cell function and may be useful in the management of impaired glucose tolerance (Wolever \& Mehling, 2002). Also, short-chain fatty acids (mainly acetate, propionate and butyrate) are the major products of carbohydrate fermentation in the colon. Among these, butyrate, which has been shown to be produced in higher proportions through fermentation of starch, has been linked to beneficial effects on the ecology of the intestinal flora and to protective effects against colon carcinoma (Williams et al. 2001). On the other hand, low small-intestinal digestibility of both starch and NSP in raw or germinated faba beans and chickpeas determined in the present study probably influence energy metabolism and growth. First, the products of carbohydrate fermentation in the large intestine, particularly short-chain fatty acids, are absorbed and utilized in the energy metabolism of the body (Mathers, 1991). Second, intraduodenal infusions of fibre (potato) evoked a tendency for an increase in the volume of secretion of pancreatic juice and a significant increase both in the mean values of the total protein content and total activities of lipase, trypsin and $\alpha$-amylase probably linked to the presence of short-chain fatty acids (Jakob et al. 2000), and exocrine pancreatic secretion and daily weight gain in pigs have been found to be positively correlated (Botermans \& Pierzynowski, 1999).

The main conclusions of the present study were that: (a) between $50-80 \%$ of the $\mathrm{N}$ found in the faeces of rats fed faba bean- or chickpea-based diets, either germinated or not, was bacterial N; (b) germination improved faecal starch and NSP digestibilities of faba bean seeds but not those of chickpeas.

\section{Acknowledgements}

The author is indebted to Mrs E. Colmenero and A. B. Rodriguez, and to Dr L. Lara and Dr D. Yañez for excellent technical assistance. Financial support was from the Spanish M.A.P.A. (project no. SC 97057).

\section{References}

Aguilera JF, Prieto C, Molina E \& Lachica M (1988) A micromethod for routine determination of chromic oxide in nutrition studies. Analysis 16, 454-457.

Ahrens F \& Kaufmann W (1985) Messungen zur fermentation im dickdarm am modell miniaturschwein unter besonderer berücksichtigung der eiweissumsetzungen (Measurements for fermentation in the large intestine of the model miniature pig with special consideration of protein conversions). Z Tierphysiol Tierernähr Füttermittelkunde 53, 150-169.

Association of Analytical Chemists (1984) Official Methods of Analysis, 14th ed. Arlington, VA: AOAC.

Ayet G, Burbano C, Cuadrado C, et al. (1997) Effect of germination, under different environmental conditions, on saponins, phytic acid and tannins in lentils (Lens culinaris). J Agric Food Chem 74, 273-279.

Bach Knudsen KE, Borg Jensen B, Andersen JO \& Hansen I (1991) Gastrointestinal implications in pigs of wheat and oat fractions. 2. Microbial activity in the gastrointestinal tract. Br J Nutr 65, 233-248.

Balcells J, Guada JA, Peiró JM \& Parker DS (1992) Simultaneous determination of allantoin and oxypurines in biological fluids by high-performance liquid chromatography. J Chromatogr 575, 153-157.

Batterham ES, Andersen LM, Saini HS \& Baigent DR (1990) Tolerance of growing pigs to trypsin and chymotrypsin inhibitors in chickpea (Cicer arietinum) and pigeon pea (Cajanus cajan) meals. Proc Aust Soc Anim Prod 18, 453.

Beames RM \& Eggum BO (1981) The effect of type and level of protein, fibre and starch on nitrogen excretion patterns in rats. Br J Nutr 46, 301-313.

Botermans JA \& Pierzynowski SG (1999) Relations between body weight, feed intake, daily weight gain, and exocrine 
pancreatic secretion in chronically catheterized growing pigs. J Anim Sci 77, 450-456.

Chavan JK, Kadam SS \& Salunkhe DK (1986) Biochemistry and technology of chickpea (Cicer arietinum L.) seeds. Crit Rev Food Sci Nutr 25, 107-158.

Chitra U, Singh U \& Rao PV (1996) Phytic acid, in vitro protein digestibility, dietary fiber, and minerals of pulses as influenced by processing methods. Plant Foods Hum Nutr 49, 307-316.

Cummings JH (1984) Microbial digestion of complex carbohydrates in man. Proc Nutr Soc 43, 35-44.

de la Cuadra C, Muzquiz M, Burbano C, et al. (1994) Alkaloid, $\alpha$-galactosides and phytic acid changes in germinating lupin seeds. J Sci Food Agric 66, 357-364.

Englyst HN, Quigley ME, Hudson GJ \& Cummings JH (1992) Determination of dietary fibre as non-starch polysaccharides by gas-liquid chromatography. Analyst 117, 1707-1714.

Fernández-Fígares I, Prieto C, Nieto R \& Aguilera JF (1997) Free amino acid concentrations in plasma, muscle and liver as indirect measures of protein adequacy in growing chickens. Anim Sci 64, 529-539.

Goodlad JS \& Mathers JC (1990) Large bowel fermentation in rats given diets containing raw peas (Pisum sativum). $\mathrm{Br} J$ Nutr 64, 569-587.

Goodlad JS \& Mathers JC (1992) Digestion of complex carbohydrates and large bowel fermentation in rats fed on raw and cooked peas (Pisum sativum). Br J Nutr 67, 475-488.

Grant G, Dorward P \& Pusztai A (1993) Pancreatic enlargement is evident in rats fed diets containing soybean (G. $\max$ ) or cowpea (V. ungiculata) for 800 days but not in those given diets based on kidney bean ( $P$. vulgaris) or lupin seed (L. angustifolius). J Nutr 123, 2207-2215.

Grant G, Edwards JE \& Pusztai A (1995) $\alpha$-Amylase inhibitor levels in seeds generally available in Europe. J Sci Food Agric 67, 235-238.

Grant G, More LM, McKenzie NH, Stewart JC \& Pusztai A (1983) A survey on the nutritional and haemagglutination properties of legume seeds generally available in the UK. Br J Nutr 50, 207-214.

Greiner R, Pedrosa MM, Muzquiz M, Ayet G, Cuadrado C \& Burbano C (1998) Effect of germination on phytate content and phytase activity in legumes. In Proceedings of the 3rd European Conference on Grain Legumes, pp. 82-84 Valladolid, Spain: AEP.

Jakob S, Mosenthin R, Thaela MJ, et al. (2000) The influence of potato fibre on exocrine pancreatic secretions and on plasma levels of insulin, secretin and cholecystokinin in growing pigs. Arch Tierernähr 53, 273-291.

Khaleque A, Elias LG, Braham JE \& Bressani R (1985) Studies on the development of infant foods from plant protein sources. Part I. Effect of germination of chickpea (Cicer arietinum) on the nutritive value and digestibility of proteins. Arch Latinoam Nutr 35, 315-325.

Khalil MM (2001) Effect of soaking, germination, autoclaving and cooking on chemical and biological value of guar compared with faba bean. Nahrung 45, 246-250.

Mansour EH (1996) Biological and chemical evaluation of chickpea seed proteins as affected by germination, extraction and $\alpha$-amylase treatment. Plant Foods Hum Nutr 49, 271-282.

Mason VC (1984) Metabolism of nitrogenous compounds in the large intestine. Proc Nutr Soc 43, 45-53.

Mathers JC (1991) Digestion of non-starch polysaccharides by non-ruminant omnivores. Proc Nutr Soc 50, 161-172.

Mathers JC, Smith H \& Carter S (1997) Dose-response effects of raw potato starch on small-intestinal escape, large-bowel fermentation and gut transit time in the rat. Br J Nutr 78, $1015-1029$.
Mosenthin R, Sauer WC, Henkel H, Ahrens F \& de Lange CFM (1992) Tracer studies of urea kinetics in growing pigs: II. The effect of starch infusion at the distal ileum on urea recycling and bacterial N excretion. J Anim Sci 70, 3467-3472.

Mossé J (1990) Nitrogen to protein conversion factor for ten cereals and six legumes or oilseeds. A reappraisal of its definition and determination. Variation according to species and to seed protein content. J Agric Food Chem 38, 18-24.

Pastuszewska B, Kowalczyk J \& Ochtabinska A (2000) Dietary carbohydrates affect caecal fermentation and modify nitrogen excretion patterns in rats. II. Studies with diets differing in protein quality. Arch Tierernähr 53, 335-352.

Rémésy C \& Demigné C (1989) Specific effects of fermentable carbohydrates on blood urea flux and ammonia absorption in the rat caecum. J Nutr 119, 560-565.

Rérat A, Simoes Nunes C, Mendy P \& Roger L (1987) Absorption kinetics of amino acids from amino acid mixtures of the same composition perfused into the small intestine in the free form or as enzymic milk protein hydrolysates in the conscious pig. Proc Nutr Soc 46, 104A.

Rubio LA (2000) Physiological effects of legume storage proteins. Nutr Abstr Rev 70A, 197-204.

Rubio LA (2003a) Determination of DAPA in rat faeces by HPLC using the Pico Tag Method. J Chromatogr 784B, $125-129$.

Rubio LA (2003b) Portal, hepatic vein and circulating plasma amino acids in rats fed lactalbumin-, faba bean- (Vicia faba) or chickpea- (Cicer arietinum) based diets. Anim Sci (In the Press).

Rubio LA, Grant G, Bardocz S, Dewey P \& Pusztai A (1991) Nutritional response of growing rats to faba beans (Vicia faba, minor) and faba bean fractions. Br J Nut 66, 533-542.

Rubio LA, Grant G, Caballé C, Martinez-Aragón A \& Pusztai A (1994) High in vivo (rat) digestibility of faba bean ( $V$. faba), lupin (L. angustifolius) and soybean (G. max) globulins. J Sci Food Agric 66, 289-292.

Rubio LA, Grant G, Daguid T, Brown D, Bardocz S \& Pusztai A (1998) The nutritional utilization by rats of chickpea (Cicer arietinum) meal and its isolated globulin proteins is poorer than that of defatted soybean or lactalbumin. J Nutr 128, $1042-1047$.

Rubio LA, Grant G, Daguid T, Brown D \& Pusztai A (1999) Organ relative weights and plasma amino acid concentrations in rats fed diets based in legume (faba bean, lupin, chickpea, soybean) seed meals or their fractions. J Sci Food Agric 79, 187-194.

Rubio LA, Grant G, Scislowsky P, Brown D, Annand M \& Pusztai A (1995) The utilization of lupin (Lupinus angustifolius) and faba bean globulins by rats is poorer than of soybean globulins or lactalbumin but the nutritional value of lupin seed meal is lower only than that of lactalbumin. J Nutr 125, 2145-2155.

Rubio LA, Muzquiz M, Burbano C, Cuadrado C \& Pedrosa MM (2002) High apparent ileal digestibility of amino acids in raw or germinated faba bean- (V. faba) and chickpea- (C. arietinum) based diets for rats. J Sci Food Agric 82, 1710-1717.

Rubio LA \& Seiquer I (2002) Transport of amino acids from in vitro digested legume proteins or casein in Caco-2 cell cultures. J Agric Food Chem 50, 5202-5206.

Savage GP \& Thompson DR (1993) Effect of processing on the trypsin inhibitor content and nutritive value of chickpeas ( $C$ arietinum). In Recent Advances of Research in Antinutritional Factors in Legume Seeds, pp. 435-440 [AFB Van der Poel, J Huisman and AS Saini, editors]. Wageningen, The Netherlands: Wageningen Pers.

Schulze H, Savelkoul FHMG, Verstegen MWA, van der Poel AFB, Tamminga S \& Groot Nibbelink SG (1997) Nutritional 
evaluation of biologically treated white kidney beans (Phaseolus vulgaris L.) in pigs: ileal and amino acid digestibility. J Anim Sci 75, 3185-3194.

Shekib LA (1994) In-vitro digestibility and microscopic appearance of germinated legume starches and their effect on dietary protein utilization. Food Chem 50, 59-63.

Surra JC, Guada JA, Balcells J \& Castrillo C (1997) Effects of post-ruminal fermentation on the faecal and urinary excretion of purines. Anim Sci 65, 383-390.

Urbano G, Lopez-Jurado M, Hernandez J, et al. (1995)
Nutritional assessment of raw, heated, and germinated lentils. J Agric Food Chem 43, 1871-1877.

Williams BA, Verstegen MWA \& Tamminga S (2001) Fermentation in the large intestine of single-stomached animals and its relationship to animal health. Nutr Res Rev 14, 207-227.

Wolever TMS \& Mehling C (2002) High-carbohydrate-low-glycaemic index dietary advice improves glucose disposition index in subjects with impaired glucose tolerance. $\mathrm{Br} \mathrm{J} \mathrm{Nutr}$ 87, 477-487. 